\title{
プランクトンネットの沪過水量に及ぼすプランクトン・ その他の影響についで
}

朝岡治** 大 和田守***

\section{On the Influence of the Plankton Organisms and Other Factors upon the Filtering Efficiency of the Plankton Net.}

\section{Osamu Asaoka and Mamoru OHwada}

\begin{abstract}
Tow flow-meters attached to a plankton net were hauled simultaneously, one being set up at the center of the mouth ring of the net, and the other $50 \mathrm{~cm}$ above. Examination was made on the relations of the ratio of the two readings of flow-meter to the settling volume and to the phytoplankton cell numbers.

Obtained results show that, when the values of settling volume and cell numbers exceed certain values, the filtering efficiency of the net is varied. Furthermore, the relation between wire angle and hauling distance is stationary when the angle is $50^{\circ}$.
\end{abstract}

\section{1. 緒言}

沪過水量を知るためにはネットの入口に沪水計 (一定方向の水流に対するプロペラの回転数から 流量を計るもの一離合社型一）をつるして引き， ブランクテストの值と比較して網目を通過した水 量を測定する方法がとられている。しかし洋上で 実施してみると，一定速度で一定距離を巻上げて る回転数はまちまちである。この原因としては, (A) 採集されたものが網目を閉塞して汇過水量 を減少させること，(B) 風圧や海流による船の移 動のために，ネットが，のばした鋼索の長さ以上 の曳網距離を示すこと，あるいは (C) 織 禾のよ じれが变化して網目の大きさを変えることや，沪 水計の機械的摩擦の增減や通過する水流の速度に よる回転数の変動などが考兄られる。この中で沪 水計の果す役割は従来いわれているょうに主とし て（A）についてであるが1)，我 々は常にプラン クトンの比較的少い外洋でばかり採集している関 係上，(A) についてその影響度のようなものを知

\section{* 1960 年 8 月 14 日受理}

** 気象庁 Japan Meteorological Agency.

**** 函館海洋気象台 Hakodate Marine Observatory.
りたいと思つていた。そこで 1959 年 5〜6 月に 行われた凌風丸の本州東方海域定期観測の際, 諸 原因のうち (A)，(B) について調査してみた。

\section{2. 装置及び方法}

使用したネットはＯ型ネットと呼ばれ，逆流 止めがついて網地には GG 54 が使用されている。 汇水計は普通使われるようにネットの入口に 1 個 と，これとは別に，実験した結果ネットの影響の 及ばないことになつた $50 \mathrm{~cm}$ 上方にさらに 1 個 とりつけた(第 2 図)。そしてこれを鋼索の長さで $100 \mathrm{~m}$ 海中に下してから約 $1 \mathrm{~m} / \mathrm{s}$ の速度で巻上

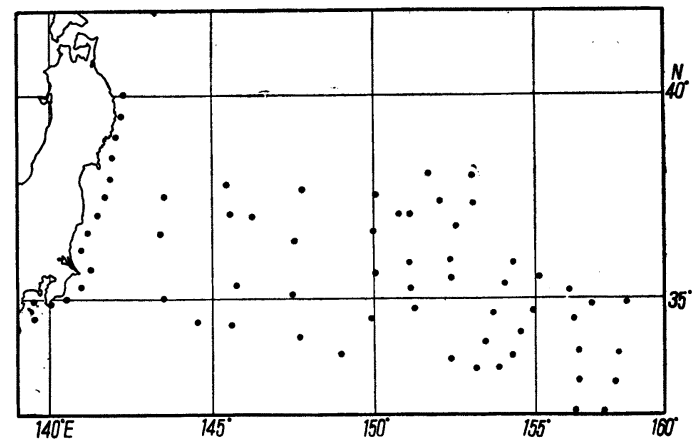

Fig. 1. Observation stations. 


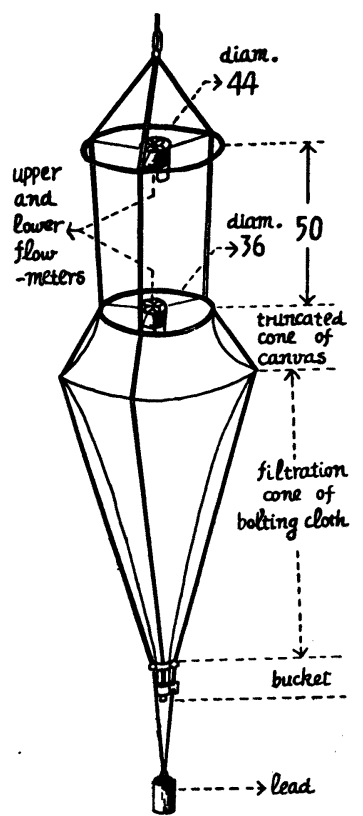

Fig. 2. Setting up of the two flow-meters (in $\mathrm{cm}$ ).

げた。こうすると上側の沪水計 $\left(F_{1}\right)$ の回転数 $\left(F_{n 1}\right)$ は網地やプランクトンに関係なく単に引い た距離に比例し,下側の沪水計 $\left(F_{2}\right)$ の回転数 $\left(F_{n 2}\right)$ は引いた距離に網地やプランクトンの影響の加わ つたものを現わすはずである。ここで $F_{n 2} / F_{n 1}$ な る比の值を考えると, 曳網距離による影響は消え て網地やプランクトンの影響がのこり，このうち 網地の影響はほぼ一定と考えれば，この比の值は プランクトンが網目を塞ぐ程度とは逆の関係に立 つものといい得よう。両汇水計の対水速度の差に よつて生ずる回転数の変化は元田・その他 ${ }^{2)} に よ$ り無視できるるのとして考光に入れてない。また 2 個の沪水計のブランクテストは第 2 田の頭錐部 と沪過部の布地をとり去つた状態で行つた。

\section{3. 結 果}

a) 第 3 困には $F_{n 1}\left(\mathrm{~A}\right.$ 㘡), $F_{n 2}$ (B 㘡) と傾角 との関倸が示してある。図中の二重丸はそれぞれ のブランクテストの平均值であり, 电網距離 100 $\mathrm{m}$ について $F_{n 2}$ の方が $F_{n 1}$ より 40 回転程多く 出るが，平滑化した線はそれよりるさらに 40 回 転程多く, 全体として $F_{n 1}$ より右に寄つて回転 数を増加したことを示している。すなわち $F_{n 2}$ は

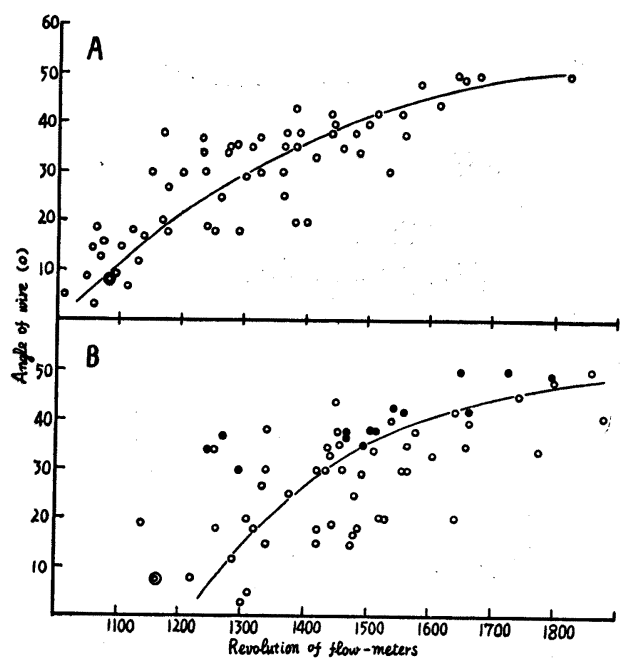

Fig. 3. Relations between revolution of two flow-meters and angle of wire (length of wire run out is always kept to be just 100 meters).
A: upper flow -meter,
B : lower flow-meter,
: coastal stations,
(a): mean value for standard calibration.

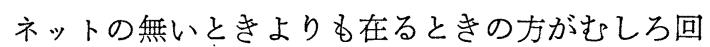
転数がふえて特り，これは頭錐部・沪過部のある ために生じた特殊な水流のためと思われる。また B 図中黒円で示してあるるのは植物プランクトン の多い沿岸観測点（第 1 図）であるが，すべて平 滑線より左側にあつて, 同一傾角でも回転数が少 くなつて閉鎖現象をよく現わしている。また全体 的に見ても $\mathrm{B}$ 図の方が点のばらつきがひどく汇 過水量が複雑に变わる様子を示している。

b) 網目の閉塞現象を起す原因になるプランク トン量を現わす目安として全沈澱量をとり，これ と $F_{n 2} / F_{n 1}$ の值との関係を示したのが第 4 図で ある。大変なばらつき方であるが，一応比の值が 小さくなるにつれて全沈澱量は增加して閉塞現象 を現わしている。さらに図の上方に散在する黒円 は Doliolum tritonis が極めて多いところから， これらが比較的浅層に密集していて沈澱量の多い 割に回転数には響かなかつたものとして例外と考 えれば，汇ぼ点線のような傾向を示するのと思わ れる。またこの罒から大ざつぱにみて全沈澱量 20〜30 cc 以下では閉塞現象をあまり問題にしな くてもよいのではないかと考えられ，乙たがつて 


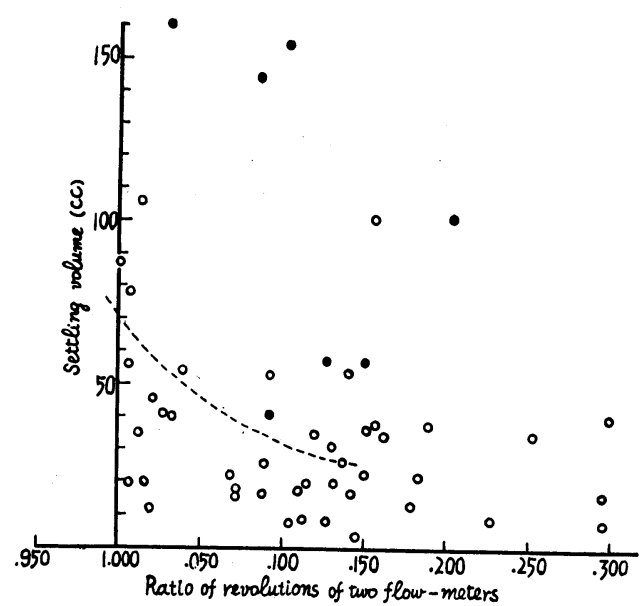

Fig. 4. Relation between the ratio of revolutions of two flow-meters and the settling volume in one haul. $O$ : stations marked with this mark are abundant in Doliolum tritonis.

$10 \mathrm{cc}$ 全沈澱量以下の場合などは，下部の沪水計 は閉塞の程度を示すよりはむしろ曳網距離を現わ するのと思われる。

c）網地に使用した GG 54 は網目の一辺の長 さが平均 $0.33 \mathrm{~mm}$ で, 理論上植物プランクトン の多くは通過しうるのであるが実際には大量に採 集されることもあり，このような場合にに動物プ ランクトン以上に網目閉塞の原因になると思われ る。しかし，今回は植物プランクトン量の影響を 調べるためにはネット採集資料は使用できず，採 水採集資料によるほかはなかつた。そこで植物プ ランクトン (Eucampia cornuta, Chaetoceros compressus) が多く, 傾角は $20 \sim 30^{\circ}$ で曳網距 離も 120 130 $\mathrm{m}$ という条件の沿岸観測点 12 点 （東京〜宮古間）をえらんで調査したものが第 5 図である。緃軸には 7 層 $(0,10,20,30,50,80$, $100 \mathrm{~m})$ の採水採集資料から得られた鉛直分布図上 で, 傾角とワイヤーの長さ $(100 \mathrm{~m})$ から求めた深 さまでの面積 $S$ を求めて, その深さまでの植物 プランクトン量を代表する数值とし，これと $F_{n 1}$ より求めた曳網距離 $l$ との積 $S \cdot l$ をるつてネッ トに入つた植物プランクトン量を現わするのとき めた。こうすると $S \cdot l=15$ あたりを境にして $F_{n 2} / F_{n 1}$ の值が 1,100〜1,150 と，これ以上に閉

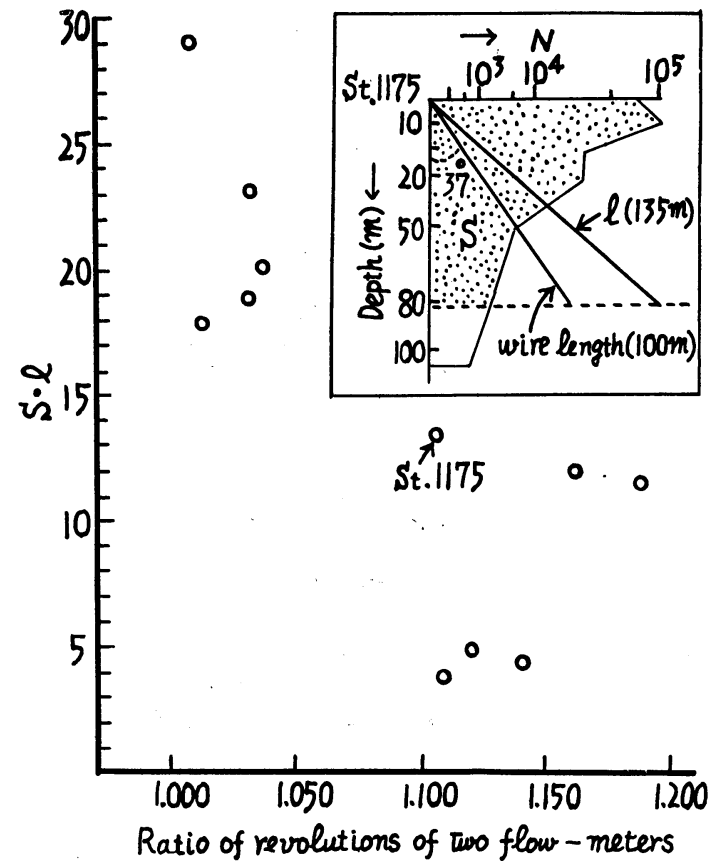

Fig. 5. Relation between the ratio of revolutions of two flow-meters and $S \cdot l$. inset: a vertical distributional pattern of phytoplankton cell numbers.

$N$ : cell numbers of phytoplankton per liter,

$l$ : hauling distance,

$S$ : an area showing the profile of vertical distribution of phytoplankton cell number in the range shallower than the depth of the net lowering.

塞した状態を示すところの $1.000 〜 1.050$ との二 つにわかれる。結局傾角や曳網距離が上述のよ5 な状態でこのネットを使用したときには，ネット の達した深さまでの植物細胞数の各層平均值にし て約 2·104（1リットル中）を越光ると急に閉塞 現象を現わしだすものということができる。

d) 傾角のない場合の回転数 $F_{n 1}$ の平均値を ワイヤーの長さ $100 \mathrm{~m}$ で割つた值は $10.6 \mathrm{r} . \mathrm{p}$. meter となり，これで個々の場合の $F_{n 1}$ を割れ ばそれぞれの史網距離を求めることができる。第 6 図にはこの值と傾角との関係が示されており, 図中の表は平滑化した際の傾角と距離の読又取り 值である。この平滑線は傾角が $45^{\circ}$ を越学ると 曳網距離はにわかに增大し，ついで定常状態に入 る傾向を示している。ここで過去の資料をしらべ てみると，傾角が $50^{\circ}$ を越える場合は極めて少 


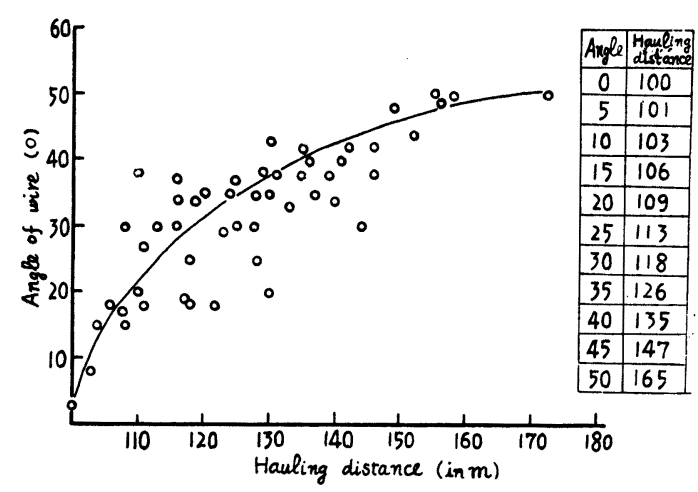

Fig. 6. Relation between angle of wire and hauling distance (calculated from the revolution of the upper flow-meter). The numbers in the table denote the readings from the smoothed curve.

くこれは現用ネットで $100 \mathrm{~m}$ のばした場合で 傾角が $50^{\circ}$ といらのはほぼ最大值と考えてよい。 また表から我々がよく経験する傾角 $20 \sim 30^{\circ}$ の ときには，史網距離はワイヤーの長さより 1〜2 割長くなることがわかる。

\section{4. 要 約}

（1）沪水計 2 個をネットの入口とその上方と
につけて同時に作動させ，主に網目を塞ぐプラン クトンの影響について調査した。

（2） 2 個の沪水計の回転数の比と全沈港量と の間にはほ涪一定の関係が認められ，全沈澱量が 20〜30 cc 以下では閉塞現象としての影響は少い ものと思われる。

（3）網地に GG 54 (網目の一辺の長さが 0.33 $\mathrm{mm}$ ）を使用しても，植物プランクトン量がある 值以上になると閉塞現象を示すことが認められ る。

（4）上方の沪水計の回転数より算出した曳網 距離と傾角之の関係は, 傾角が $50^{\circ}$ 近辺に達す ると定常状態となる。

\section{文献}

1） 中井甚二郎, 1954: プランクトンネット用沪水 計解説, 東海区水研鱝資源科.

2) МотоdA S., et al., 1957: Experiments on the performance of plankton samplings with net. Bull. Fac. Fish., Hokkaido Univ., Vol. 8, No. 1. 